\title{
Potential Use of Banana and Its By-products: A Review
}

\author{
Gajendra Kumar Rana ${ }^{1}$, Yogendra $\operatorname{Singh}^{2}$, S. P. Mishra ${ }^{1}$ and Hemant K. Rahangdale ${ }^{1}$ \\ ${ }^{1} M G C G V V$, Chitrakoot, Satna (M P), India \\ ${ }^{2} J N K V V$, Jabalpur (MP), India \\ *Corresponding author
}

\begin{tabular}{|c|c|}
\hline & A B S T R A C T \\
\hline & \multirow{5}{*}{$\begin{array}{l}\text { The interest in study of waste management is being increased worldwide } \\
\text { presently as the pollution by various means are made day by day. The waste } \\
\text { utilization plays a vital role to overcome these pollutions and make possible } \\
\text { to utilize the waste. Bananas plant has no use after harvesting the fruit, but } \\
\text { it is used in following context significantly: viz. producing bioethanol, } \\
\text { single cell protein, cellulase, citric acid, lactic acid, amylase, cosmetics, } \\
\text { fibre, bio-film, paper, bio-plastic bio-electricity in the agro-industry, } \\
\text { pharmaceuticals, bio-medical and bio-engineering aspect etc. However } \\
\text { besides these banana peels also used as bio-sorbent for treatment of water } \\
\text { by removal of nitrites from drinking water, antifungal and antibiotic } \\
\text { purpose. }\end{array}$} \\
\hline & \\
\hline $\begin{array}{l}\text { Musa spp., } \\
\text { Aspergillus spp., } \\
\text { waste utilization }\end{array}$ & \\
\hline Article Info & \\
\hline $\begin{array}{l}\text { Accepted: } \\
\text { 18 May } 2018 \\
\text { Available Online: } \\
10 \text { June } 2018\end{array}$ & \\
\hline
\end{tabular}

\section{Introduction}

Banana is a tropical fruit grown in over 122 countries worldwide. Until 2004, the cultivated area of 3.8 million hectares and a total production of 56.4 million metric tonnes of the fruit were produced ranking it fourth behind rice, corn and milk (Chai et al., 2004; Arumugam and Manikandan, 2011).

In recent times, Banana peel has been utilized for various industrial applications including bio-fuel production, bio-sorbents, pulp and paper, cosmetics, energy related activities, organic fertilizer, environmental cleanup and biotechnology related processes (Morton,
1987; Gunaseelan, 2004; Bori et al., 2007). Its mass cultivation and consumption in the recent decades made it the world second largest fruit crop with an estimated gross production exceeds 139 million tonnes (FAO 2010). World leading banana and plantain producers are India, China, Uganda, Ecuador, Philippines, and Nigeria. The native people have been utilizing these plants more than just for food purposes but have begun to explore the possibilities of utilizing banana plants in their daily life. Banana plantation occupies large part of the land, but it is a contamination source because after harvest, the tree is cut down and abandoned in the fields, which foments Sigatoka (Chillet, et al., 2009). 
Potential Use of Banana and Its Byproducts

Antibacterial activity of ethanolic and aqueous extract of banana peels

All parts of the banana plant have medicinal applications, the flowers in bronchitis and dysentery and on ulcers; cooked flowers are given to diabetics; the astringent plant sap in cases of hysteria, epilepsy, leprosy, fevers, haemorrhages, acute dysentery and diarrhoea, and it is applied on haemorrhoids, insect and other stings and bites; young leaves are placed as poultices on burns and other skin afflictions; the astringent ashes of the unripe peel and of the leaves are taken in dysentery and diarrhea and used for treating malignant ulcers.

Ehiowemwenguan, et al., (2014) investigated the in vitro antibacterial activity of ethanolic and aqueous extract of banana (Musa sapientum) peels on both gram-positive and gram-negative bacteria using agar well diffusion technique. The ethanolic extract of the peels had MIC values ranging from $16 \mathrm{mg} / \mathrm{ml}$ to $512.5 \mathrm{mg} / \mathrm{ml}$. The least MIC was $16 \mathrm{mg} / \mathrm{ml}$ against Salmonella typhi while Bacillus subtilis and Staphylococcus aureus showed the highest MIC of $512.5 \mathrm{mg} / \mathrm{ml}$. In the aqueous extract the MIC ranged between $512.5 \mathrm{mg} / \mathrm{ml}$ to $>1025 \mathrm{mg} / \mathrm{ml}$. Salmonella typhi, Micrococcus luteus and Staphylococcus aureus were not inhibited by the water extract. Phytochemical result showed ethanol to be a better solvent for the extraction of the bioactive agents in banana peels which include: glycosides, alkaloids, saponins, tannins, flavonoids and volatile oil.

\section{Production of bioethanol by banana wastes}

In the present scenario, bio-fuels have increased in popularity because of rising oil prices and the need for energy security. India imports $>70 \%$ of its required crude oil, which leads a major expenditure of foreign currency. India can cut its crude oil import by using bioethanol for vehicles. (Shindo and Tachibana, 2006).

Itelima et al., (2013) reported that after 7 days of fermentation, pineapple peels had the highest biomass yield of 1.89 (OD), followed by banana peels $1.60(\mathrm{OD})$, while plantain peels had the least 0.98 (OD). The reducing sugar concentrations ranged between 0.27 $0.94 \mathrm{mg} / \mathrm{cm} 3$ for pineapple, $0.20-0.82$ $\mathrm{mg} / \mathrm{cm} 3$ for banana and $0.16-0.45 \mathrm{mg} / \mathrm{cm} 3$. The optimal ethanol yields were $8.34 \% \mathrm{v} / \mathrm{v}$, $7.45 \% \mathrm{v} / \mathrm{v}$ and $3.98 \% \mathrm{v} / \mathrm{v}$ for pineapple, banana and plantain peels respectively. These indicate that pineapple and banana peels ethanol yields were significantly higher $(\mathrm{P}<0.05)$ than plantain peel ethanol yield. The findings of this study suggest that wastes from fruits that contain fermentable sugars can no longer be discarded into our environment but should be converted to useful products like bio-ethanol that can serve as alternative energy source.

\section{Production of single cell protein}

The term SCP refers to dead, dry microbial cells or total proteins extracted from puremicrobial cell culture and is produced using a number of different micro-organisms including bacterium, fungus and algae. It can also be called biomass, bioprotein or microbial protein.

A comparative study of fruit wastes revealed that cucumber peel generates higher amount of protein followed by that of orange with $53.4 \%$ and $30.5 \%$ crude protein respectively per $100 \mathrm{gm}$ of substrate used. Percentage of protein in single cell protein was much lower $(17.47 \%)$ when Saccharomyces cerevisiae was grown on supplemented fruit hydrolysate medium that contained inorganic nitrogen 
sources but devoid of glucose. Addition of glucose to the supplemented fruit hydrolysate medium enhanced the protein content $(60.31 \%)$ within the yeast cell. Thus, the single cell protein production by yeast depends on the growth substrates or media composition. (Bhowal et al., 2012).

\section{Production of cellulase by banana peel waste}

Celluloses, Hemicelluloses, Pectin, starch etc. form bulk of agricultural wastes. Hydrolysis of these substrates yields fermentable sugars that can be processed further as chemical feedstock or fuel. The recent stress on renewable energy resources demands a proper utilization of these.

Baig et al., (2003) found that the 127 fungi isolated from the soil of banana field, 12 fungi were found to utilize cellulose as source of carbon. Trichoderma lignorum showed appreciable cellulolytic activity. It produced $\mathrm{C} 1, \mathrm{Cx}$ and $\mathrm{b}$ glucosidase in Carboxymethyl Cellulose Peptone medium as well as on agro waste based medium containing leaves, stem and rhizome powders. T. lignorum $(0.45 \mathrm{U} / \mathrm{ml})$ produced maximum enzymes on leaf based medium

\section{Production of lactic acid by various waste peels}

Lactic acid, classified as GRAS (generally regarded as safe) for use as food additive by the US FDA (Food and Drug Administration) can be produced by either microbial fermentation or chemical synthesis. Fruit based industry produces large volume of wastes.

Umesh M and K Preethi, (2014.) carried out the fermentative production of LA from various fruit peel waste (mango, orange, banana and pineapple) as substrates by employing Lactoctobacillus plantarum as the starter culture. The highest lactic acid production was obtained from mango peels (10.08 g/L), whereas the other substrates viz. orange peels, banana peels and pineapple peels produced $5.74 \mathrm{~g} / \mathrm{L}, 4.68 \mathrm{~g} / \mathrm{L}$ and 4.68 $\mathrm{g} / \mathrm{L}$ of lactic acid respectively.

\section{Production of amylase from peel of banana}

Amylase production has increased dramatically due to its wide spread use in food, textile, baking and detergent industries. Commercially amylase is produced by using Starch as a substrate and organisms used are Bacillus subtilis and Bacillus diastaticus.

Result of study conducted by Jadhav et al., (2013) observed that the amylase yield from the fermentation medium was 0.7 units $/ \mathrm{ml}$ for Aspergillus niger and 0.8 units/ml for Bacillus subtilis which are known amylase producers. But one of the isolate i.e. $\mathrm{BS}_{9}$ gave a maximum yield of 1.55 units/ml after $72 \mathrm{hrs}$.

But the surprising results were obtained within just 24hrs. By $\mathrm{PB}_{1}$ as 1.36 units $/ \mathrm{ml}$ which can be considered as a very good yield. The additional nitrogen source peptone did not show any significant increase in the amylase yield.

\section{Use of banana peel as bio-sorbent for treatment of water}

The ground water available in the country, in general, is potable and suitable for various usages. The commonly observed contaminants such as Arsenic, Fluoride and Iron are geogenic (occurring due to natural causes mainly through rock-water interaction), whereas contaminants such as nitrates, phosphates, heavy metals etc. owe their origin to various human activities including domestic sewerage, agricultural practices and industrial effluents. 
Reddy et al., (2015) studied that the feasibility of use of banana peels as a Bio sorbent in removal of nitrate from the drinking water.

The effect of different parameters like contact time, adsorbent size fraction, adsorbent dosage, nitrate concentration was studied. The removal efficiency of nearly $80 \%$ was achieved when $0.05 \mathrm{~g}$ of banana peel powder of $106 \mu \mathrm{m}$ size fraction was used as adsorbent to treat $100 \mathrm{ml}$ of contaminated water sample of $200 \mathrm{mg} / \mathrm{l}$ nitrate concentration for a contact time of $0.5 \mathrm{~h}$.

\section{Production of fibre, film and paper from banana pseudo stem}

Banana growing worldwide importance of the utilization of various non-wood plant fibres, as an alternative to wood pulp, in the manufacture of pulp, paper and paper board is now well established. Many non-wood fibres such as bamboo, jute, straw, rice, and abaca are currently used in small commercial pulping operation.

Banana stem has no use after harvesting the fruit, Pulping is done to liberate the fibres from lignin and hemicelluloses, which can be accomplished chemically or mechanically or by combining these two types of treatment. Chemical pulping is characterized by the use of chemicals to separate the lignin fraction of lignocelluloses materials from the cellulose. Chemical separation results in little or no effect on the fibre length. Kappa number, yield, viscosity limit index $(\mathrm{cm} 3 / \mathrm{gm})$ is used to describe the extent of lignin removal in the cooking process.

There are five pulping techniques, namely kraft process, sulphite process, soda process, formic acid /acetic acid solvent and Urea/NaOH solvent system were studied. (Kumar and Kumar, 2011).

\section{Production of bio plastic from banana waste}

Advancements in the use of waste materials could also significantly improve the economics of the biopolymer, biomaterial products, paper and pulp industries by leading to new sources of raw materials and other innovations. Cellulose is modified to obtain a thermoplastic material, by acetylation (cellulose acetate). After acidic treatment, and elimination of the amorphous parts of cellulose microfibrils, the whiskers (monocrystals) are obtained, which are used to develop nano composites materials.

Hossain, (2015) found Biomasses can be the source of biomaterial products such as bioplastics, bio-film, bio-plastic based materials, bioethanol as antiseptic and use of cosmetic industries, bio-chemicals, bio-fuels, and bioelectricity in the agro-industry, pharmaceuticals, biomedical and bioengineering aspect and study was conducted to prepare nano-cellulose sized particle for the multiple uses in the industry.

Nanoparticle size was found $50 \mathrm{~nm}$ and compared with the standard. Cellulose was found higher in nanosized particle than without nanosized particle. However, $\mathrm{pH}$ was found alkaline of nanosized particle which was under the standard value. Current results can conclude that it is possible to prepare banana peel lingo-cellulosed based nanoparticle.

This study led to the conclusion that the whole banana plant is useful as food, feed, pharmaceuticals, packaging and many other industrial uses. Fruits are rich source of antioxidants, minerals viz KandFe. Pseudostem is a waste product after harvesting the fruit can be used as potential source of cellulose to make high valued cellulose-based products such as paper, fibre, etc. 
The relevant clinical applications and waste utilization of action is still to be the area of research. This can have serious consequences.

\section{References}

Arumugam, R., and Manikandan, M., 2011. Fermentation of pretreatedhydrolyzates of banana and mango fruit wastes for ethanol production. Asian Journal of Biological Science 2: 246-256.

Babu, P H., Reddy, C A., Prashanthi, N., and Mahal,e J S., 2015. Banana Peel as a Biosorbent in Removal of Nitrate from Water, International Advanced Research Journal in Science, Engineering and Technology. 2 (10), 95-98.

Baig, M M V., Mane, V P., More, D R., Shinde, L P., and Baig, M I A., 2003. Utilization of banana agricultural waste: Production of cellulases by soil fungi, Journal of Environmental Biology, 24(2), $173-176$.

Bhowal, et al., 2012. Utilization of fruit wastes in producing single cell protein, International Journal of Science, Environment and Technology, 1(5), 430-438.

Bori, M.O., Adebusoye, S. A., Lawal, A. K., and Awotiwon, A., 2007. Production of biogas from banana and plantain peels. Advanced Environmental Biology 1: 33-38.

Chai, M., Ho, Y. W., Liew, K. W. and Asif, J.M., 2004. Biotechnology and in vitro Mutagenesis for Banana Improvement. In: Banana Improvement: Cellular, Molecular Biology and Induce Mutations, Jain, S. and R. Swennen (Eds.). Science Publisher Inc., USA, Pp: 59-77.

Chillet, M., Abadie, C., Hubert O., ChilinCharles Y., and Bellaire L D. 2009. Sigatoka Disease Reduces the Greenlife
On Bananas. Crop Protection, 28(1), 4145.

Ehiowemwenguan, G., Emoghene, A O., and Inetianbo, R J E., 2014. Antibacterial and phytochemical analysis of Banana fruit peel, Journal of Pharmacy, 4 (8), $18-25$.

FAO (2010) FAOSTAT: Banana Production by Countries $2010 \quad \mathrm{http}: / /$ faostat.fao.org/site/339/default.aspx.

Gunaseelan, N., 2004. Biochemical methane potential of fruits and vegetable solid waste feedstocks. Biomass and Bioenergy 26: 389-399.

Hossain, A B M S., 2015. Nano-Particle Preparation from Ligno-Cellulose Based Banana Peel Biomass as a Tool of Nano-Biotechnology, global journal of biology, Agriculture and Health sciences, 4(3), 19-21.

Iralapati, V., and Kummari, S., 2014. Production of Citric Acid from Different Fruit Peels Using Aspergillus niger, International Journal of Scientific Engineering and Research, 3 (5), 129130.

Itelima, J., Onwuliri, F., Onwuliri, E., Onyimba, I., and Oforji, S., 2013. BioEthanol Production from Banana, Plantain and Pineapple Peels by Simultaneous Saccharification and Fermentation Process, International Journal of Environmental Science and Development, 4,(2),213-216.

Jadhav, S A., et al., 2013. Amylase Production from Potato and Banana Peel Waste, Int.J.Curr.Microbiol.App.Sci, 2 (11), 410-414.

Kumar, M., and Kumar, D., 2011. Comparative study of pulping of banana stem, International Journal of Fibre and Textile Research 2011; 1(1): 1-5.

Morton, J., 1987. Fruits of warm climates. Durian 1: 287-291. 
Shindo, S., and Tachibana, T., 2006. Umesh, M., and Preethi, K., 2014. Production of bioethanol from spent grain - a by-product of beer production. Tech. Q. Master Brew. Assoc. Am., 43: 189-193. Fermentative Utilization of Fruit Peel Waste for Lactic Acid Production by Lactobacillus plantarum, Indian Journal of Applied Research, 4 (9), 449-451.

\section{How to cite this article:}

Gajendra Kumar Rana, Yogendra Singh, S. P. Mishra and Hemant K. Rahangdale. 2018. Potential Use of Banana and Its By-products: A Review. Int.J.Curr.Microbiol.App.Sci. 7(06): 1827-1832. doi: https://doi.org/10.20546/ijcmas.2018.706.218 